\title{
ВПЛИВ ДИСИДЕНТСЬКО-ПРАВОЗАХИСНОГО РУХУ НА РОЗВИТОК УКРАЇНСЬКИХ ПРАВОЗАХИСНИХ ГРОМАДСЬКИХ ОРГАНІЗАЦІЙ
}

\author{
НАУМЕНКО Олена Петрівна - аспірантка кафедри теорії, історії права \\ і держави та конституційного права Навчально-наукового інституту права \\ Університету державної фіскальної служби України
}

DOI:10.32782/LAW.2020.1.5

УДК: 061.2:342.7]:316.647.6]](477)(09)(045)

\begin{abstract}
У статті приділено увагу історї розвитку правозахисних громадських організащій «часів інакодумства». Важливим поштовхом у бормуванні неурядових організачій нового демократичного спрямування став дисидентський рух, що особливо актуалізувався та набув поширення в СРСР, та в Україні зокрема, в 1960-1980-ті роки.
\end{abstract}

Попри значний доробок вчених з проблематики дисиденства, корелятивному аналізу впливу дисидентсъкого руху на генезу громадських правозахисних організачій приділено недостатньо уваги. Комплексне ж вивчення будь-якого явища, правозахисних організачій неурядового сектору зокрема, не можливе без з'ясування рушійних важелів, що визначили його існування у сучасному вигляді. Тому метою даної розвідки стало з'ясування впливу дисидентсъкого руху, особливо його правозахисного напрямку, на бормування украӥнсъких правозахисних громадських організаиій.

Встановлено, що дисидентсъко-правозахисний рух 60-80-х років відіграв важливу роль у розвитку украӥнськоӥ громадськой самоорганізачиї, пропагуючи ідеї правової держави, самочінності особистості, превалювання загальнолюдських ијнностей над класовими, визначив передумови нової суспільної ситуаиї, сприяв трансбормащй свідомості украӥнсъкого суспільства щодо не можливості подальшого демократичного поступу без реального дотримання прав людини, у тому иислі права народу на начіональне самовизначення.

З’ясовано, що започатковані ним традиції знайшли своє продовження у діяльності су- часних правозахисних організаиій, зокрема найбільшої в Украӥні асочіачй правозахисних організацій - Українсъкої Гельсінсъкої спілки 3 прав людини.

Ключові слова: права людини, дисидентство, дисидентсвкий рух, правозахисний рух, громадсъкі правозахисні організачй.

Постановка проблеми, стан наукової розробленості та аналіз останніх досліджень

Правозахисний дисидентський рух - унікальне явище нещодавнього історичного минулого. Обумовлене множиною соціальноекономічних і політичних факторів, воно має глибокі історичні корені.

3 початку 90-х рp. XX ст. проблематика дисидентського руху, українського зокрема, перебуває в центрі уваги широкого кола як українських, так і зарубіжних дослідників. У працях О. Бажана, Т. Батенка, О. Даніеля, Ю. Данилюка, А. Богораз, Ю. Зайцева, Г. Касьянова, В. Кіпіані, А. Русначенка та ряду інших вчених здійснено спроби з'ясувати витоки дисидентського руху, обгрунтувати його хронологічні рамки, представити діяльність окремих інакодумців, гуртків, груп, організацій. Визначальним дослідженням історії українського дисидентського руху $є$ монографія А. Русначенка, де автором акцентовано на спадкоємності та безперервності українського визвольного руху, розглянуто національний, культурницький правозахисний i робітничий рухи в Україні середини 1950-х - початку 1990-х років. У працях Б. Захаро- 


\section{Теорія, історія держави і права, конституційне право}

ва, Ю. Данилюка, О. Бажана висвітлюється історія різних дисидентських напрямів та течій в Україні.

Попри значний доробок вчених з окресленої тематики, корелятивному аналізу впливу дисидентського руху на генезу громадських правозахисних організацій приділено недостатньо уваги. Комплексне ж вивчення будь-якого явища, правозахисних організацій неурядового сектору зокрема, не можливе без з'ясування рушійних важелів, що визначили його існування у сучасному вигляді. Тому метою даної розвідки є з'ясування впливу дисидентського руху, особливо його правозахисного напрямку, на формування українських правозахисних громадських організацій.

\section{Виклад основного матеріалу}

Однією $з$ ознак правової держави є не лише декларативне закріплення прав і свобод людини, а й їх гарантування. Реальне забезпечення прав і свобод досягається шляхом створення механізму їх всебічної захищеності та встановлення відповідальності за порушення [1].

Слушно зазначає Ю.С. Шемшученко, що на довгому історичному шляху від Стародавньої Греції та античного Риму, де суспільство i держава ототожнювалися, до сучасної наукової концепції громадянського суспільства у суспільній свідомості сформувалось уявлення, що держава не завжди є надійним гарантом прав та інтересів окремої особи і суспільства. Що ж може змусити державу бути таким гарантом? Соціальною силою, спроможною урівноважити силу держави та зобов'язати останню 3 нею рахуватися, є громадянське суспільство [2, с. 10].

Яскравим наочним підтвердженням означеної тези виступає дисидентсько-правозахисний рух, що був проявом боротьби громадянського суспільства проти радянського тоталітаризму та створив якісно нові умови для розвитку громадських організацій нової формації, орієнтованих у своїй діяльності передусім на утвердження загальнолюдських цінностей та захист прав людини.

Визначення поняття дисидентства, його наукової періодизації, співвідношення понять «дисидентство» та «інакодумство», «дис- идентський» та «правозахисний», «опозиційний», «національно-визвольний» рухи і нині є досить дискусійними питаннями, про що свідчить велике розмаїття їх трактувань.

Більшість дослідників обмежують дисидентство 60-80-ми роками ХХ століття. На думку Бажана О.Г., їм цілком аргументовано заперечує Рой Мєдвєдєв та робить висновок, що дисидентство як явище в різних формах існувало на всіх етапах розвитку як радянського суспільства, так і будь-якого суспільства взагалі [3, с. 28; 4, с. 239].

Схожої позиції дотримується і Юрій Аyкін, зазначаючи, що «...в будь-якому суспільстві є не лише ті, хто схвалюють офіційну політику, індиферентні конформісти, але і не згодні, інакомислячі, що виступають проти пануючої релігії, ідеології, існуючої політичної системи, способу життя». В історії тому 6 багато прикладів: «протестантизм, інші реформаційні течії в історії християнства, розкол в Російській православній церкві в XVII столітті, протопіп Авакум, антифеодальні виступи, геліоцентризм Коперника, Джордано Бруно, Галілея... протести робітників, страйки, мітинги, антивоєнні, екологічні та інші акції в XV столітті» [5, с. 105].

Щодо витоків українського дисидентства, то, зокрема Ю.Т. Аитвин вважає, що воно бере свій першопочаток ще з ідей української козацької держави, самовідданої боротьби народу проти соціального, національного та релігійного поневолення, знаходить органічне продовження в творчості Тараса Шевченка, в державотворчих традиціях української революції 1917-1920 рр. [6, с. 364].

Доречно акцентує В.В. Овсієнко, що хоча «ідею прав людини українські мислителі висловлювали ще в XIX ст. (Михайло Драгоманов, Богдан Кістяківський та інші); у неявній формі вона також була важливою складовою частиною Конституції УНР 1918 року, але рух, який свідомо ставив перед собою мету домогтися визнання прав людини державою... - явище, що виникло тільки в 60-х рр., на тлі критики культу особи й «казарменного комунізму», у період хрущовської «відлиги» [7].

Безпосередня учасниця правозахисного руху $\mathcal{\lambda}$. Алєксєєва в свою чергу відзначає, що оформлення правозахисників в соціальний рух відбулося в СРСР мише в 1960-ті роки. 
На їі переконання, саме в цей період почали мати місце спільні сумісні дії різних соціальних груп, що були об'єднані: 1) спільною метою - змінити свій соціальний статус; 2) спільними цінностями,... 3) спільною системою норм, регулюючих та регламентуючих поведінку їх учасників; 4) неформальним лідером, роль якого змінюеться по мірі розвитку руху соціального,...5) специфічними способами символізації своїх цінностей в політичній ідеології [8]. Особливістю правозахисного руху в СРСР було те, що він не набув форми соціального інституту, що володів би специфічними нормами і санкціями, а грунтувався лише на єдиних цінностях і цілях [9].

Вчена виокремлюе такі етапи в історії його розвитку: 1953-1964 рр. - початок; 1965-1968 рр. - перші правозахисні виступи; 1968-1972 рр. - становлення; 1973-1974 рр. - криза; 1974-1975 рр.- подолання кризи; 1976-1981 рр. - гельсінський період; 19801983 рр. - після розрядки [8]. Серед цих ключових дат в якості рубіжних визначають: кінець 1969-го року - організаційне оформлення; друга половина 1970-х років - період, «червоною ниткою» яких стали Гельсінські угоди; початок 1980-х років - знищення руху [9].

Думку, що громадський правозахисний рух в радянській державі розпочався саме 3 дисидентського періоду поділяє і Г. Майстренко, пропонуючи таку періодизацію правозахисного руху в Російській Федерації: радянський або точніше дисидентський - 3 1965 р. до 1985 р.; «період перебудови» - до 1995 р.; сучасний [10, с. 36].

Своєрідний підхід до визначення етапів правозахисного руху запропоновано А.B. Гавриловою: період становлення (1965-1968 рр.) - період від процесу Даніеля і Синявського до «Пражської весни»; другий період (1968-1975 рр.) - період кризи та широкого міжнародного визнання; третій - гельсінський (1976-1985 рр.); четвертий - період легалізації правозахисної діяльності (1985 р. - по теперішній час). Авторка відзначає ще про існування так званого «передправозахисного етапу», обгрунтовуючи це тим, що боротьба народу за свої права мала місце і під час сталінського режиму, однак вона не могла набути масового та організованого харак- теру в умовах тотального терору. «Невеликі групи та співтовариства існували і в 1930ті, і в 1940-ті роки, але, будучи в глибокому підпіллі, вони не могли здійснити суттєвого впливу на події в країні» [11, с. 152].

Дисидентський рух був різновекторним соціальним явищем. Переважна частина науковців виокремлюе в якості основних 3-и його напрямки (течії): правозахисний, національно-орієнтований та релігійний [8; 11, с. 12; 12, с. 617]. Слід погодитися з Т.В. Гавронською, що останній є набагато менш притаманним радянській Росії порівняно 3 братерськими республіками, зокрема і Україною, оскільки питання національного самовизначення в Росії лежало дещо в іншій площині, керівництво РСФСР значною мірою ініціювало процеси культурної та національної асиміляції [11, с. 179]. Безумовно означені напрями дисидентства не слід розглядати ізольовано - слушно зазначає О. Бажан, що «в практиці опозиційного руху у рамках досліджуваного періоду вони нерідко виступали зі спільних позицій, згуртованою силою» [3, с. 30-31]. В Україні ж боротьба за права людини завжди відбувалась на тлі прагнення народу до національної незалежності. Заслуговує на увагу позиція С. Захарова, який на підставі аналізу історичних документів та спогадів дисидентів, дійшов висновку, що український дисидентський рух в радянській державі «був найсильнішим» та відзначався, окрім національної специфіки, ще і регіональними особливостями в межах самої України - «можна стверджувати, що на Західній Україні дисидентський рух переважно приймав форму національно-визвольного, а на Східній - національний і релігійний рухи з'єднувалися $з$ правозахисним [13, с. 312, с. 315].

Метою правозахисного напрямку дисидентського руху була спроба досягти «гласності» і покращення ситуації з політичними, економічними, особистими та іншими правами людини [7], продемонструвати хибність комуністичної ідеології, оманливість «соціалізму 3 людським обличчям», що знаходив уособлення в особливій радянській концепції правового статусу особи і громадянина. Як відзначає О.I. Аушин, «в СРСР людина (особистість, громадянин) розглядалася пе- 


\section{Теорія, історія держави і права, конституційне право}

редусім як трудівник-колективіст, учасник спільної справи, що вершилась під керівництвом та контролем партії. Такою спільною справою було будівництво основ соціалізму та рух до комунізму, колективізація, індустріалізація, виконання п'яти- і семилітніх планів і т.п.» В усіх випадках особі відводилася лише роль своєрідного «гвинтика державного механізму, трудового резерву, людського фактору, виробничої сили». Виступаючи в таких іпостасях, вона завжди служила чомусь надособистому, далекому від іiї власних потреб та інтересів [14].

Кожний період ознаменувався певними подіями. Але вже на етапі становлення в 1969 році була створена перша в СРСР правозахисна асоціація «Ініціативна група захисту прав людини в СРСР» (IГ) [15, с. 153]. 3 України до групи увійшли харків' янин Генріх Алтунян та киянин Леонід Плющ. Приєднався до асоціації також Мустафа Джемілєв - лідер руху кримських татар за повернення до Криму, - що на той час мешкав у Ташкенті. Діяльність організації зводилась до петиційних компаній: подання заяв, звернень до різних радянських та міжнародних установ щодо стану з правами людини в СРСР, або ж на захист окремих інакодумців, що були піддані репресіям. На прохання Петра Якіра - члена IГ - Генріх Алтунян разом 3 однодумцями (54 особи) підписали відкритого листа до Верховної Ради СРСР на захист кримських татар і П. Григоренка, заарештованого на початку травня 1969 року. Серед підписантів були: Аеонід Плющ, В’ячеслав Чорновіл, Семен Подольський та інші. В травні 1969 року ІГ було направлено звернення і до Комітету ООН з прав людини про стан дотримання прав та свобод людини в СРСР. Згодом більшість учасників цих акцій стали об'єктами переслідувань з боку влади: когось було засуджено, хтось отримав суворі догани по місцю роботи, або ж взагалі був звільнений з посади [13, с. 316]. На жаль, діяльність IГ тривала не довго та перервалась у зв'язку з арештом влітку 1972 року ї̈ очільників П. Якіра, В. Красина.

На думку науковця А.В. Гаврилової, саме досвід легальної роботи цієї організації надихнув та переконав інших у можливості діяти відкрито. Як наслідок, у 1970 році був створений Комітет прав людини в СРСР, що був першою незалежною громадською організацією $з$ розробленим регламентом та правилами членства, а також першою незалежною асоціацією СРСР, що отримала формальне міжнародне визнання: в червні 1971 року комітет став філіалом Міжнародної ліги прав людини - неурядового об'єднання зі статусом консультативного органу при ООН, ЮНЕСКО і МОТ та увійшов до Міжнародного інституту права. Вчена акцентує, що, хоча першопочатково комітет організовувався як дослідницька і консультативна організація, до його членів зверталася велика кількість людей з проханням у захисті своїх прав - від перегляду судових вироків до сприяння у виїзді за кордон [15, с. 153].

У серпні ж 1975 року сталася подія - підписання Прикінцевого акта Наради 3 безпеки і співробітництва в Европі, - яка «мала таке важливе значення, що дозволяє поділити історію правозахисного руху в Україні на період до цієї події і після неї» [7].

Не зважаючи на протидію владних структур, після опублікування згаданого акту в газеті «Известия», 3 метою втілення міжнародної домовленості у життя, у різних регіонах Радянського Союзу почали створюватися групи сприяння виконання Гельсінських угод. 12 травня 1976 р. була організована Московська громадська група (скорочено МГГ). На ії кшталт аналогічні організації виникають і в союзних республіках. Першою після московської (до речі, на думку С. Захарова, за ініціативою члена російської групи, українця за походженням Петра Григоренка [16]., з позиції О. Бажана - достеменно не відомо хто був ідейним зачинателем створення, але однозначно у витоків стояли і Микола Руденко, і Олесь Бердник, і Оксана Мешко, i Левко Аук'яненко, і Петро Григоренко. $[17$, с. 74]), 9 листопада 1976 року, - Українська громадська група сприяння виконанню Гельсінських угод (скорочено - УГГ), трохи згодом - Аитовська (25 листопада того ж року), 14 січня 1977 р. - Грузинська і 1 квітня - Вірменська. На Україні, Литві та у Вірменії ї ці групи були першими відкритими громадськими асоціаціями [15, с. 153].

Найголовнішою відмінністю правозахисного руху цього періоду від рухів і течій по- 
передніх було те, «що правозахисники вже не протиставляли себе системі, а діяли всередині неї, намагаючись боротися законним, легальним шляхом, прагнули змусити владу виконувати міжнародні угоди, власну Конституцію та закони» [13, с. 315].

УГГ взяла на себе координацію всього правозахисного руху в українській республіці, ії діяльність дала змогу привернути увагу прогресивної світової громадськості до проблем української нації і свобод громадян в Україні, сприяла формуванню єдиного загальнонаціонального правозахисного центру, відіграла позитивну роль в консолідації опозиційного руху в Україні [17, с. 77].

Утворення Гельсінських груп сприяло появі спеціалізованих правозахисних організацій, найбільш відомі 3 яких, щоправда, були переважно загальносоюзного значення. Так, у 1977 році при МГГ була створена Робоча комісія 3 розслідування використання психіатрії у політичних цілях; в березні 1978 року - Ініціативна група захисту прав інвалідів в СРСР», в середині 1979 р. - група «Право на еміграцію» та інші.

Слід відзначити, що на думку деяких науковців, Робоча комісія з розслідування використання психіатрії вважається однією 3 найбільш ефективних правозахисних асоціацій того часу [15, с. 153]. Організація активно займалась збором інформації про політичних в'язнів та інакомислячих, що утримувалися в психіатричних лікарнях. III зусиллями були скорочені строки утримання в спеціалізованих медичних закладах правозахисників Володимира Борисова, Петра Старчика, Едуарда Федотова. Та одним із значних досягнень асоціації стало ухвалення Міжнародним з'їздом психіатрів в 1977 р., на підставі поданих нею для обговорення документів, Резолюції щодо засудження психіатричних репресій в Радянському Союзі [15, с. 153]. Співпрацював 3 комісією харківський дисидент, психіатр Анатолій Корягін - проводив незалежні психіатричні експертизи, друкував в самвидаві праці про репресивну психіатрію. За свою діяльність він згодом був підданий переслідуванню, заарештований та засуджений у лютому 1981 року [13, с. 317].

В контексті аналізу дисидентського руху в Україні не можливо не згадати і релігій- ний його напрямок. Історично склалося, що боротьба за права віруючих в Українській греко-католицькій церкві (УГКЦ) й Українській автокефальній православній церкві (УАПЦ) відбувалася по-різному. Існування таких церков в Україні влада не визнавала, їх прихильників та віруючих жорстоко переслідувала. Першою правозахисною організацією на захист прав віруючих УГКЦ стала «Ініціативна група захисту прав віруючих і церкви в Україні», створена 9 вересня 1982 р. До їі складу увійшли Йосип Тереля , отець Григорій Будзінський, отці Ігнатій та Діонісій, Стефанія Петраш-Січко. Незважаючи на створювані перепони, протягом усього часу панування радянської влади рух УГКЦ не вщухав [13, с. 318$].$

Українська автокефальна православна церква, була ліквідована більшовиками в 1930 році, іï священики, монахи й віруючі піддані репресіям. Частково відновлена під час німецької окупації, після війни УАПЦ існувала тільки в екзилі. Як зазначає Е. Захаров, «в Україні не було руху УАПЦ, проте був один православний священик, правозахисник, який уособив боротьбу українського православ'я за права людини в Україні - Василь Романюк, багаторічний політв'язень, член УГГ, а згодом - патріарх Володимир» [13, c. 318].

Гонінь зазнавали і протестантські конфеciï. У лютому 1964 була створена правозахисна організація ЕХБ, очолювана Аідією Вінс - «Рада родичів в’язнів євангельських християн-баптистів», що проіснувала більше 15 років.

\section{Висновки}

Отже, дисидентсько-правозахисний рух 60-80- $\mathrm{x}$ років здійснив значний вплив на розвиток української громадської самоорганізації, пропагуючи ідеї правової держави, толерантності, самоцінності особистості, превалювання загальнолюдських цінностей над класовими та партійними, ідею відмови від будь-якого насилля, заклав передумови нової суспільної ситуації, сприяв трансформації свідомості українського спільноти щодо не можливості подальшого демократичного поступу без реального дотримання прав людини, у тому числі права народу на національ- 


\section{Теорія, історія держави і права, конституційне право}

не самовизначення. Традиції, започатковані ним, живуть і донині. Сучасна Українська Гельсінська спілка з прав людини, що «стала правонаступницею УГГ, своєю метою визначає реалізацію та захист прав людини й основних свобод через сприяння практичному виконанню гуманітарних статей Прикінцевого акта Гельсінської наради з безпеки і співробітництва в Европі 1975 року, інших прийнятих на його розвиток міжнародноправових документів та зобов'язань України у сфері прав людини та основних свобод» [18], налічуючи на даний час близько 30-ти представників, є найбільшою асоціацією правозахисних організацій в Україні [19], здійснюе правозахисну діяльність по різним напрямкам, являється родоначальницею багатьох прогресивних зрушень в цій сфері, а тому займає чільне місце в авангарді українського громадянського суспільства.

\section{Лiтература}

1. Філософія права : підруч. для студ. юрид. вищ. навч. закл. / О. Г. Данильян, О. П. Дзьобань, С. І. Максимов та ін./ за ред. О. Г. Данильяна. Харків : Право, 2017. 208 с.

URL: http://ibrary.nlu.edu.ua/POLN TEXT/4\%20KURS/4/2/001start.htm

2. Громадянське суспільство в Україні: сучасний стан, виклики, стратегія модернізації: монографія: У 2 т. / за заг. ред. акад. НАН України Ю.С. Шемшученка та акад. НАПрН України О. В. Скрипнюка / Т. 1: Загальнотеоретичні та конституційно-правові аспекти розвитку громадянського суспільства в Україні. Київ : Юридична думка, 2018. 676 с.

3. Бажан О. Г. Дисиденство в УРСР: спроба дефініції. Магістеріум. Вип. 7. Історичні студії. НаУКМА. К. : Стилос, 2001. C. 27-31. URL:http://ekmair.ukma.edu.ua/ bitstream/handle/123456789/13960/Bazhan Dysydenstvo v URSR sproba definitsii. pdf?sequence $=1$ \&isAllowed $=\mathrm{y}$

4. Медведев Р. Личность и эпоха: Политический портрет $\mathcal{\Lambda}$. И. Брежнева. Кн. I. М. : Изд-во Новости, 1991. 336 с.

5. Аукин Ю. Ф. Из истории сопротивления тоталитаризму в СССР (20-80-е гг.). М. : Издательство Московского государственного университета, 1992. 204 с.
6. Литвин Ю. Правозахисний рух на Україні, його засади та перспективи. Українська суспільно-політична думка в 20 ст. Т. III. Б.м. : Сучасність, 1983.

7. Овсієнко В. В. Правозахисний рух в Україні. Українська Громадська Група сприяння виконанню Гельсінських угод: В 4 т. T. 1. Особистості. Харківська правозахисна група: упорядн. Є. Ю. Захаров. Харків : Фоліо, 2001. 26.02.2008. Віртуальний музей. Дисидентський рух в Україні. URL: http:// museum.khpg.org/index.php?id = 1204026181 (дата звернення: 01.03.2020).

8. ᄉ. Алексеева. История инакомыслия в CCСP. Мемориал. URL: http://old.memo. ru/history/diss/books/alexeewa/index.htm (дата звернення: 01.03.2020).

9. Гарькин И. Н., Королева А. А. Правозащитное движение в СССР (1960-1980 гг.). История и археология. 2014. № 4 URL: http:// history.snauka.ru/2014/04/959 (дата звернення: 01.03.2020).

10. Майстренко А. Г. Неправительственные правозащитные организации в Российской Федерации : дис. ... канд. юрид. наук: 12.00.02 / М.: РГБ, 2003. 177 с. /Из фондов Российской Государственной библиотеки/ Полный текст. URL :http://diss.rsl.ru/ diss/03/0507/030507013. (дата звернення: 01.03.2020).

11. Гавронська Т. В. Дисидентські рухи як спроба реалізації свободи слова і дії особистості. Науковий часопис НПУ імені М.П. Драгоманова. Серія 18. Економіка і право. 2013. Вип. 22. С. 176-183. URL: http://nbuv. gov.ua/U」RN/Nchnpu $018 \quad 2013 \quad 22 \quad 26$ (дата звернення: 01.03.2020).

12. Березовский В. М. Движение диссидентов в СССР в 60-х - первой половине 80-х годов. Россия в ХX веке: Историки мира спорят. М.: Наука, 1994. С. 616-618.

13. Захаров Б. Е. Напрями і течії дисидентського руху в Україні (1956-1987). URL: periodicals.karazin.ua > article (дата звернення: 01.03.2020).

14. Аушин А. И. История правозащитного движения в России как образовательный и воспитательный компонент. ИТС. 2003. № 4. URL: https://cyberleninka.ru/article/n/ istoriya-pravozaschitnogo-dvizheniya-v-rossii- 
kak-obrazovatelnyy-i-vospitatelnyy-komponent (дата звернення: 07.03.2020).

15. Гаврилова А. В. Трансформация диссидентско-правозащитного движения в неправительственные правозащитные организации. Вестник КемГУ. 2008. № 4. URL: https://cyberleninka.ru/article/n/transformatsiya-dissidentsko-pravozaschitnogo-dvizheniya-vnepravitelstvennye-pravozaschitnye-organizatsii (дата звернення: 07.03.2020).

16. Захаров Б. Є. Дисидентський рух в Україні (1954-1987) 03.11.2006. Віртуальний музей. Дисидентський рух в Україні. RLU: http://museum.khpg.org/index. php?id $=1162536313$ (дата звернення: 01.03.2020).

17. Бажан О. Г. Українська Гельсінська група: легальна форма протистояння тоталітарному режимові в УРСР. С. 73-78. RLU: http://ekmair.ukma.edu.ua/bitstream/ handle/123456789/10461 (дата звернення: 01.03.2020).

18. «Наша свобода не далася дарма». Українська Гельсінська група. 27.10.2016. Український інститут національної пам'яті. URL: https://uinp.gov.ua/informaciyni-materialy/vchytelyam/metodychni-rekomendaciyi/ nasha-svoboda-ne-dalasya-darma-ukrayinskagelsinska-grupa (дата звернення: 01.03.2020).

19. Місія та історія спілки. 19.02.2016. Українська Гельсінська Спілка з прав людини. URL: https://helsinki.org.ua/informatsiya/ (дата звернення: 01.03.2020).

\section{Referens}

1. Filosofiia prava : pidruch. dlia stud. yuryd. vyshch. navch. zakl. / O. H. Danylian, O. P. Dzoban, S. I. Maksymov ta in./ za red. O. H. Danyliana. Kharkiv : Pravo, 2017. 208 s.

URL: http://ibrary.nlu.edu.ua/POLN TEXT/4\%20KURS/4/2/001start.htm

2. Hromadianske suspilstvo $\mathrm{v}$ Ukraini: suchasnyi stan, vyklyky, stratehiia modernizatsii: monohrafiia: U 2 t. / za zah. red. akad. NAN Ukrainy Yu.S. Shemshuchenka ta akad. NAPrN Ukrainy O.V. Skrypniuka / T. 1: Zahalnoteoretychni ta konstytutsiino-pravovi aspekty rozvytku hromadianskoho suspilstva $\mathrm{v}$ Ukraini. Kyiv : Yurydychna dumka, 2018.676 s.

3. Bazhan O.H. Dysydenstvo v URSR: sproba definitsii. Mahisterium. Vyp. 7.
Istorychni studii. NaUKMA. K. : Stylos, 2001. S. 27-31. URL:http://ekmair.ukma.edu.ua/ bitstream/handle/123456789/13960/Bazhan Dysydenstvo_v URSR sproba definitsii. pdf? sequence $=1$ \&isAllowed $=\mathrm{y}$

4. Medvedev R. Lichnost' i jepoha: Politicheskij portret L.I. Brezhneva. M., 1991. Kn. I.

5. Lukin Ju. F. Iz istorii soprotivlenija totalitarizmu v SSSR (20-80-e gg.). M. : Izdatel'stvo Moskovskogo gosudarstvennogo universiteta, 1992. $204 \mathrm{~s}$.

6. Lytvyn Yu. Pravozakhysnyi rukh na Ukraini, yoho zasady ta perspektyvy. Ukrainska suspilno-politychna dumka v 20 st. T. III. B.m. : Suchasnist, 1983.

7. Ovsiienko V.V. Pravozakhysnyi rukh v Ukraini. Ukrainska Hromadska Hrupa spryiannia vykonanniu Helsinskykh uhod: V 4 t. T. 1. 26.02.2008. Virtualnyi muzei. Dysydentskyi rukh v Ukraini. URL: http://museum.khpg.org/ index.php?id=1204026181 (data zvernennia: 01.03.2020).

8. L. Alekseeva. Istorija inakomyslija $\mathrm{v}$ SSSR. Memorial. URL: http://old.memo.ru/ history/diss/books/alexeewa/index.htm (data zvernennja: 01.03.2020).

9. Gar'kin I.N., Koroleva L.A. Pravozashhitnoe dvizhenie v SSSR (1960-1980 gg.). Istorija i arheologija. 2014. \# 4 URL: http:// history.snauka.ru/2014/04/959 (data zvernennja: 01.03.2020).

10. Majstrenko A. G. Nepravitel'stvennye pravozashhitnye organizacii $\mathrm{v}$ Rossijskoj Federacii : dis. ... kand. jurid. nauk: 12.00.02 / M.: RGB, 2003. 177 s. Iz fondov Rossijskoj Gosudarstvennoj biblioteki. Polnyj tekst. URL :http://diss.rsl.ru/diss/03/0507/030507013. (data zvernennja: 01.03.2020).

11. Havronska T.V. Dysydentski rukhy yak sproba realizatsii svobody slova $\mathrm{i}$ dii osobystosti. Naukovyi chasopys NPU imeni M.P. Drahomanova. Seriia 18. Ekonomika i pravo. 2013. Vyp. 22. S. 176-183. URL: http://nbuv. gov.ua/UJRN/Nchnpu_018_2013_22_26 (data zvernennia: 01.03.2020).

12. Berezovskij V. M. Dvizhenie dissidentov v SSSR v 60-h - pervoj polovine 80-h godov. Rossija v XX veke: Istoriki mira sporjat. M.: Nauka, 1994. S. 616-618. 


\section{Теорія, історія держави і права, конституційне право}

13. 13. Zakharov B.Ye. Napriamy i techii dysydentskoho rukhu v Ukraini (1956-1987) URL: periodicals.karazin.ua , article (data zvernennia: 01.03.2020).

14. .Lushin A.I. Istorija pravozashhitnogo dvizhenija $\mathrm{v}$ Rossii kak obrazovatel'nyj i vospitatel'nyj komponent. ITS. 2003. \# 4. URL: https://cyberleninka.ru/article/n/istoriyapravozaschitnogo-dvizheniya-v-rossii-kakobrazovatelnyy-i-vospitatelnyy-komponent (data zvernennja: 07.03.2020).

15. Gavrilova A.V. Transformacija dissidentsko-pravozashhitnogo dvizhenija v nepravitel'stvennye pravozashhitnye organizacii. Vestnik KemGU. 2008. \# 4. URL: https:// cyberleninka.ru/article/n/transformatsiyadissidentsko-pravozaschitnogo-dvizheniya-vnepravitelstvennye-pravozaschitnye-organizatsii (data zvernennja: 07.03.2020).

16. Zakharov B.Ye. Dysydentskyi rukh v Ukraini (1954-1987) 03.11.2006. Virtualnyi muzei. Dysydentskyi rukh v Ukraini. RLU: http:// museum.khpg.org/index.php?id = 1162536313 (data zvernennia: 01.03.2020).

17. Bazhan O.H. Ukrainska Helsinska hrupa: lehalna forma protystoiannia totalitarnomu rezhymovi v URSR. S. 73-78. RLU: http://ekmair.ukma.edu.ua/bitstream/ handle/123456789/10461 (data zvernennia: 01.03.2020).

18. «Nasha svoboda ne dalasia darma». Ukrainska helsinska hrupa 27.10.2016. Ukrainskyi instytut natsionalnoi pam'iati. URL: https://uinp.gov.ua/informaciyni-materialy/ vchytelyam/metodychni-rekomendaciyi/ nasha-svoboda-ne-dalasya-darma-ukrayinskagelsinska-grupa (data zvernennia: 01.03.2020).

19. Misiia ta istoriia spilky. 19.02.2016. Ukrainska Helsinska Spilka z prav liudyny. URL: https://helsinki.org.ua/informatsiya/ (data zvernennia: 01.03.2020).

\section{Naumenko $O$. \\ IMPACT OF DISSIDENT HUMAN RIGHTS MOVEMENT ON THE DEVELOPMENT OF UKRAINE'S HUMAN \\ RIGHTS SOCIAL ORGANIZATIONS}

The article deals with history of human rights social organizations "in the era of dissent". A significant impact on formation of new democracy-oriented nongovernmental organizations was provided by the dissident movement which became particularly active and spread across the USSR, including Ukraine, in 1960s-1980s.

Despite the significant achievements of scholars who studied variuos issues of the dissident movement, correlative analysis of the impact of the dissident movement on the genesis of human rights social organizations is still rather neglected. A comprehensive study of any social phenomenon, in particular human rights organizations in the nongovernmental sector, is not possible without identifying the driving forces that have determined its existence in contemporary form. That is why the aim of this research was to determine the impact of the dissident movement, in particular its human rights wing, on formation of Ukraine's human rights social organizations.

It has been established that the dissident human rights movement of 1960s -1980s played an important role in developing self-organization of the Ukrainian society, propagating notions of the state that follows the rule of law, intrinsic value of a person, prevalence of universal human values over class differences. The movement outlined preconditions for a new social situation, contributed to transformation of the Ukrainian national consciousness by showing that further progress of democracy was not possible without strict compliance with human rights standards, including norms pertaining to the right of a people to national self-determination.

The research states that the traditions established by the movement have inspired activities of the present-day human rights organizations, in particular those of the largest association of human rights organizations in Ukraine - the Ukrainian Helsinki Human Rights Union.

Key words: human rights, human rights movement, dissidence, dissident movement, human rights social organizations. 